\title{
Potensi Sekam Padi dan Jerami sebagai Alternatif Material Akustik
}

\author{
Ahmad Minanur Rohim* , Fianti, dan Upik Nurbaiti \\ Prodi Pendidikan Fisika, Program Pascasarjana Universitas Negeri Semarang Kampus \\ Kelud - Jalan Kelud Utara III, Gajahmungkur, Semarang 50237, Indonesia \\ *email: nurminan3@gmail.com
}

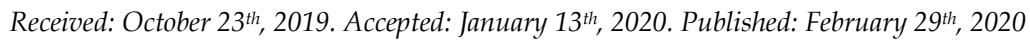

\begin{abstract}
Abstrak
Teknologi yang semakin berkembang menghasilkan peralatan berupa sarana informasi, komunikasi, produksi, transportasi maupun hiburan. Sebagian besar peralatan tersebut menghasilkan kebisingan. Kebisingan dapat dikurangi dengan menggunakan peredam akustik. Penelitian ini bertujuan mengetahui potensi serap bunyi dari sekam padi dan jerami sebagai material akustik alami. Material yang digunakan antara lain: sekam padi, jerami, dan resin. Sampel dibuat bentuk seperti silinder sebanyak 12 buah. Sampel yang sudah dibuat diuji menggunakan alat ukur serap bunyi yaitu tabung impedensi untuk mengukur nilai koefisien serap bunyi sampel. Hasil pengujian menunjukkan nilai koefisien serap bunyi (a) dipengaruhi oleh ketebalan. Pada frekuensi $500 \mathrm{~Hz}$ nilai koefisien serap bunyi $(\alpha)$ setiap sampel sebesar $0,034 \mathrm{~dB}$; $0,030 \mathrm{~dB} ; 0,030 \mathrm{~dB} ; 0,027 \mathrm{~dB} ; 0,026 \mathrm{~dB} ; 0,027 \mathrm{~dB} ; 0,025 \mathrm{~dB} ; 0,025 \mathrm{~dB}$; $0,025 \mathrm{~dB} ; 0,024 \mathrm{~dB} ; 0,024 \mathrm{~dB} ; 0,023 \mathrm{~dB} ; 0,023 \mathrm{~dB}$. Bahan sempel yang bagus dalam penelitian pada bahan 1 dan 2 yang mempunyai daya serap bunyi sebesar $0,034 \mathrm{~dB}$ dan $0,030 \mathrm{~dB}$.
\end{abstract}

\begin{abstract}
Technology that is increasingly developing produces equipments in the form of information, communication, production, transportation and entertainment facilities. Most of the equipments produce noises. Noise can be reduced by using
\end{abstract}

doi: 10.21580/perj.2020.2.1.4883

https://ejournal.walisongo.ac.id/index.php/perj/index 
acoustic dampers. This study aims to determine the potential for sound absorption from rice husks and straw as natural acoustic materials. Materials used include rice husks, rice straw, and resin. 12 cylindrical samples were made. Samples that have been made are tested using a sound absorption measuring instrument that is the impedance tube to measure the value of the sample sound absorption coefficient. The test results show the value of the sound absorption coefficient (a) can be influenced by the thickness. At a frequency of $500 \mathrm{~Hz}$ the value of the sound absorption coefficient $(\alpha)$ for each sample is $0.034 \mathrm{~dB} ; 0.030 \mathrm{~dB} ; 0.030 \mathrm{~dB} ; 0.027 \mathrm{~dB} ; 0.026 \mathrm{~dB} ; 0.027 \mathrm{~dB} ; 0.025 \mathrm{~dB}$; $0.025 \mathrm{~dB} ; 0.025 \mathrm{~dB} ; 0.024 \mathrm{~dB} ; 0.024 \mathrm{~dB} ; 0.023 \mathrm{~dB} ; 0.023 \mathrm{~dB}$. The sample material is good in research on materials 1 and 2 which have a sound absorption of $0.034 \mathrm{~dB}$ and $0.030 \mathrm{~dB}$. C2020PERJ

Keywords: Absorption potential; composite; rice husk; rice straw; wave.

\section{PENDAHULUAN}

$\begin{array}{llr}\begin{array}{c}\text { Teknologi } \\ \text { berkembang, }\end{array} & \text { yang } & \begin{array}{r}\text { semakin } \\ \text { membuat }\end{array} \\ \text { perkembangan } & \text { peralatan yang }\end{array}$
digunakan manusia semakin meningkat (Waytz, Heafner, \& Epley, 2014). Peralatan tersebut berupa sarana informasi, komunikasi, produksi, transportasi maupun hiburan (Ashari, Heidari, \& Parvaresh, 2014). Akan tetapi, peralatan tersebut menghasilkan suara-suara yang tidak diinginkan sehingga menimbulkan kebisingan (Astika \& Dwijana, 2016). Salah satu cara untuk mencegah perambatan/radiasi kebisingan pada komponen/struktur mesin, ruangan/bangunan serta dalam konteks K3 kebisingan industri ialah dengan penggunaan material akustik, yaitu material yang bersifat menyerap atau meredam suara sehingga bising yang terjadi dapat direduksi (Muhammad Munir, 2015).

Kebisingan merupakan bunyi yang tidak diharapkan (Waytz et al., 2014). Kebisingan sangat mengganggu bahkan berbahaya bagi manusia sehingga diperlukan suatu material yang dapat mengurangi atau bahkan menyerap intensitas bunyi (Bahri, T.N. Manik, \& Suryajaya, 2016). Salah satu dampak kebisingan adalah gangguan pendengaran, yang merupakan perubahan pada tingkat pendengaran sehingga menyebabkan kesulitan untuk melakukan aktivitas sehari-hari (Tun, Williams, Small, \& Hafter, 2012). Kesulitan tersebut biasanya 
dalam hal memahami pembicaraan. Tingkat gangguan pendengaran karena kebisingan dapat ditentukan menggunakan parameter percakapan sehari-hari (Ulfayanti, 2016).

Komposit merupakan material yang terbentuk dari kombinasi dua atau lebih bahan pembentuknya melalui campuran yang tidak homogen (Julius Novel Sagitta, I Ketut Gede Sugita, 2017). Pencampuran tersebut akan menghasilkan material komposit yang mempunyai sifat mekanik dan karakteristik yang berbeda dari material pembentuknya (Firman, Hasbi, \& Aksar, 2018). Material penyerap bunyi mempunyai peranan penting dalam akustik ruangan, perancangan studio rekaman, ruang perkantoran, sekolah, sekolah, dan ruang lain untuk mengurangi kebisingan yang umumnya sangat mengganggu (Luzzi \& Busa, 2018). Material ini disebut material akustik yang fungsinya adalah untuk menyerap dan meredam suara (Suhaemi, Tongkukut, \& As'ari, 2013). Penelitian ini menyoroti cara yang dapat dilakukan untuk memperbaiki perilaku akustik komposit serat alami sebagai peredam kualitas tinggi, dikombinasikan dengan bahan peraga biologis sehingga mengurangi kecacatan dan risiko dari komposit (Ferreira \& Fantuzzi, 2017). Sebagai tambahan, limbah serabut kelapa sebenarnya tidak berdampak pada lingkungan (Dharmawan, Suardana, Istri, \& Kusuma, 2018).

\section{METODE}

Penelitian ini termasuk jenis penelitian eksperimen laboratorium dengan menggunakan Tabung Impedansi. Penelitian ini dilakukan di Laboratorium Fisika Fakultas Sains dan Teknologi Universitas Islam Negeri Walisongo Semarang.

\section{Alat}

Alat yang digunakan dalam penelitian ini adalah cetakan berdiameter $3 \mathrm{~cm}$, neraca digital, oven, pengaduk, gelas ukur, mika astralon, vaselin, blender dan 1 set alat pengukuran intensitas bunyi yang dilengkapi dengan audio generator, dan kabel penghubung.

\section{Bahan}

Bahan yang digunakan dalam penelitian ini adalah sekam padi, jerami, dan resin.

\section{Variabel Penelitian}

Variabel yang digunakan dalam penelitian ini adalah perbandingan sekam padi, jerami dan resin. Perbandingan campuran tiap sampel pada Tabel 1 dibuat variasi berbeda pada campuran jerami dengan variasi yang sama pada sekam padi dan resin. 
Tabel 1. Perbandingan Campuran Tiap

\begin{tabular}{ccc} 
Sampel & & \\
\hline $\begin{array}{c}\text { Sekam Padi } \\
\text { (gram) }\end{array}$ & $\begin{array}{c}\text { Jerami } \\
\text { (gram) }\end{array}$ & $\begin{array}{c}\text { Resin } \\
\text { (gram) }\end{array}$ \\
\hline 1 & 0,2 & 3 \\
1 & 0,4 & 3 \\
1 & 0,6 & 3 \\
1 & 0,8 & 3 \\
1 & 1 & 3 \\
1 & 1,2 & 3 \\
1 & 1,4 & 3 \\
1 & 1,6 & 3 \\
1 & 1,8 & 3 \\
1 & 2 & 3 \\
1 & 2,2 & 3 \\
\hline
\end{tabular}

Tahapan Penelitian

Langkah-langkah pembuatan material sekam padi dan jerami sebagai berikut:

1) Bahan baku sekam padi dan jerami dikeringkan dengan menggunakan oven.

2) Bahan baku sekam padi dan jerami diblender sampai halus.

3) Siapkan cetakan sampel berukuran diameter $3 \mathrm{~cm}$ kemudian lapisi dengan vaselin dan mika astralon.

4) Material ditimbang sesuai dengan komposisi pada Tabel 1.

5) Material diaduk dan dimasukkan ke dalam cetakan.

6) Sampel didiamkan pada ruang tertutup.

7) Setelah kering, sampel ditimbang dan diukur koefisien serap pada tiap sampel.

\section{HASIL DAN PEMBAHASAN}

Koefisien serap bunyi sangat dipengaruhi oleh frekuensi sumber suara tersebut. Frekuensi dibagi menjadi 3, yaitu frekuensi rendah $(0-1000 \mathrm{~Hz})$, frekuensi sedang $(1000-4000 \mathrm{~Hz})$, dan frekuensi tinggi $(>4000 \mathrm{~Hz})$. Tabung impedansi dapat digunakan untuk menentukan nilai koefisien serap bunyi, yaitu dengan cara mengukur energi suara yang datang dan suara yang dipantulkan. Pengujian dilakukan pada malam hari dimulai dari jam 5 sore di Laboratorium Fisika Fakultas Sains dan Teknologi Universitas Islam Negeri Walisongo Semarang. Hal ini bertujuan untuk mengurangi suara yang dapat mengganggu kerja dari tabung impedansi tersebut. Pengukuran pada frekuensi $500 \mathrm{~Hz}$ dengan bahan pada Tabel 1 didapatkan koefisien serap bunyi seperti yang disajikan pada Tabel 2.

Setiap material komposit mempunyai sifat akustik yang berbeda. Setiap komposit memiliki nilai optimum penyerapan bunyi pada frekuensi tertentu. Sifat akustik komposit penyerap bunyi sangat baik pada frekuensi $1000 \mathrm{~Hz}$. Hal tersebut disebabkan pada frekuensi tersebut terjadi pembuangan energi yang mengakibatkan terjadinya kenaikan serapan bunyi. Setelah mencapai titik optimum, nilai serap bunyi 
akan cenderung menurun. Hal ini disebabkan material komposit cenderung bersifat resesif, yaitu akan mengalami penurunan sifat akustik pada frekuensi tertentu. Pada frekuensi $4000 \mathrm{~Hz}$ terjadi peningkatan koefisien serap bunyi pada setiap komposit. Hal ini disebabkan terjadinya interferensi konstruktif pada frekuensi tersebut, sehingga mengakibatkan koefisien serap bunyi meningkat.

Tabel 2. Data Koefisien Serap Cahaya

\begin{tabular}{cccccc}
\hline $\begin{array}{c}\mathrm{f} \\
(\mathrm{Hz})\end{array}$ & Sampel & $\begin{array}{c}\text { Tebal sampel } \\
(\mathrm{cm})\end{array}$ & $\begin{array}{c}\mathrm{I}_{0} \\
(\mathrm{~dB})\end{array}$ & $\begin{array}{c}\mathrm{I}_{\mathrm{T}} \\
(\mathrm{dB})\end{array}$ & $\begin{array}{c}\mathrm{a} \\
(\mathrm{dB})\end{array}$ \\
\hline & 1 & 0,585 & 35,7 & 35 & 0,033850645 \\
& 2 & 0,7 & 35,7 & 34,95 & 0,030331743 \\
& 3 & 0,76 & 35,7 & 34,9 & 0,029820868 \\
& 4 & 0,87 & 35,7 & 34,87 & 0,027038883 \\
500 & 5 & 0,92 & 35,7 & 34,84 & 0,026504931 \\
& 6 & 1,01 & 35,7 & 34,8 & 0,025280497 \\
& 7 & 1,08 & 35,7 & 34,75 & 0,024973256 \\
& 8 & 1,13 & 35,7 & 34,71 & 0,024887486 \\
& 9 & 1,19 & 35,7 & 34,69 & 0,024116998 \\
& 10 & 1,24 & 35,7 & 34,67 & 0,02360962 \\
& 11 & 1,29 & 35,7 & 34,65 & 0,023141832 \\
& 12 & 1,34 & 35,7 & 34,63 & 0,022709202 \\
\hline
\end{tabular}

Sampel 1 dan 2 memiliki daya serap bunyi yang paling bagus dibandingkan sampel yang lain. Ini terjadi karena komposit dengan tebal yang lebih besar mempunyai ruang yang lebih besar untuk menyerap energi bunyi. Sampel yang lebih tebal belum tentu memiliki koefisien serap bunyi yang lebih baik (Mediastika, 2008). Hal ini benar hanya untuk bunyi frekuensi rendah namun tidak selalu untuk frekuensi tinggi.

\section{KESIMPULAN}

Kesimpulan yang dapat diambil dalam eksperimen yang sudah dilakukan yaitu bahan sampah organik seperti sekam padi dan jerami dapat dimanfaatkan sebagai bahan dasar pembuatan peredam bunyi. Bahan sampel yang bagus dalam penelitian terdapat pada bahan 1 dan 2 yang mempunyai daya serap bunyi sebesar $0,034 \mathrm{~dB}$ dan $0,030 \mathrm{~dB}$. 


\section{DAFTAR PUSTAKA}

Ashari, H. A., Heidari, M., dan Parvaresh, S. 2014. Improving SMTEsâ Business Performance through Strategic Use of Information Communicati-on Technology: ICT and Tourism Challenges and Opportunities. Internatio-nal Journal of Academic Research in Accounting, Finance and Management Sciences, 4 (3): 120.

Astika, I. M. dan Dwijana, I. G. K. 2016. Karakterstik Serapan Suara Komposit Polyester Berpenguat Serat Tapis Kelapa. Dinamika Teknik Mesin, 6 (1): 8-14.

Bahri, S., Manik, T. N., dan Suryajaya. 2016. Pengukuran Sifat Akustik Material Dengan Metode Tabung Impedansi Berbasis Platform Arduino. Jurnal Fisika Flux, 13 : 148-154.

Dharmawan, I. M. S., Suardana, N. P. G., Istri, C., dan Kusuma, P. 2018. Analisa Koefisien Penyerapan Suara dan Kekuatan Impact Komposit Hybrida Batu Apung Dengan Variasi Fraksi Volume Serat Sabut Kelapa 20 \% Dan 25 \%/ Gypsum. Jurnal Ilmiah TEKNIK DESAIN MEKANIKA, 7 (2): 165-169.

Ferreira, A. dan Fantuzzi, N. 2017. Mechcomp3.

https://doi.org/10.15651/978-
88-9385-029-2

Firman, Hasbi, M. dan Aksar, P. 2018. Studi Eksperimen Kekuatan Mekanik Daun Nanas Hutan Dengan Metode Pengujian Tarik. Jurnal Ilimiah Mahasiswa Teknik Mesin, 3 (1): 1-7.

Julius Novel Sagitta, I Ketut Gede Sugita, C. I. P. K. K. 2017. Variasi Ketebalan Panel Green Komposit Terhadap Koefisien Serap Bunyi Komposit Serabut Kelapa (Cocos Nuciferal) Dengan Perekat Getah Pinus (Pinus Merkusii). Jurnal Ilmiah TEKNIK DESAIN MEKANIKA, 6 (4): 318-322.

Luzzi, S. dan Busa, L. 2018. Acoustic Smartness And Sustainability In Urban Planning And Building Design. Euronise, (43): 837-844.

Mediastika, C. E. 2008. Kualitas Akustik Panel Dinding Berbahan Baku Jerami. DIMENSI (Jurnal Teknik Arsitektur), 36 (2): 127-134.

Muhammad Munir, D. 2015. Pemanfaatan Fluk pada Styrofoam sebagai Bahan Dasar Peredam Suara dengan Metode Tabung Impedansi. Jurnal Inovasi Fisika Indonesia, $04: 41-47$.

Suhaemi, T., Tongkukut, S. H. J., dan As'ari. 2013. Koefisien Serap Bunyi Papan Partikel Dari Bahan Serbuk Kayu Kelapa. Jurnal MIPA Unsrat, 2 (1): 56-59. 
Tun, P. A., Williams, V. A., Small, B. J., dan Hafter, E. R. 2012. The effects of aging on auditory processing and cognition. American Journal of Audiology, 21 (2): 344-350.

Ulfayanti, A. 2016. Studi Karakteristik Material Akustik Berbahan Sandwich Kertas Koran dan Gabus dengan Perekat Sagu. Waytz, A., Heafner, J., dan Epley, N. 2014. The mind in the machine: Anthropomorphism incre-ases trust in an autonomous vehicle. Journal of Experimental Social Psychology, 52 : 113-117. 
Phy. Educ. Res. J. Vol. 2 No. 1 (2020), 35-42 